\title{
PENGARUH TATA KELOLA PERUSAHAAN TERHADAP MANAJEMEN LABA PADA PERUSAHAAN DAGANG YANG TERDAFTAR DI BURSA EFEK INDONESIA
}

\author{
Alvin, Viola Syukrina E Janrosl \\ Universitas Putera Batam, Indonesia \\ Email: pb160810082@upbatam.ac.id
}

\begin{abstract}
The purpose of this study is to learn about the governance arrangements for earnings management in trading entities, and investment in the trade subsector on the Indonesia Stock Exchange in 2014-2018. Entity governance is organized into 3 variable compositions, institutional ownership, managerial ownership and audit committee. Earnings management variables were collected with discretionary accrual using the Jones model. Data collection method in this research is purposive sampling. The sample amounted to 27 entities that are part of 10 companies that are taken from the company in the trade, services and investment sectors with the retail trade subsector listed on the Indonesia Stock Exchange in the period 2014-2018. The research method used is the multiple regression method to analyze the independent variables on the dependent variable. The results showed that corporate governance towards earnings management in this study stated by the T Test and F Test. The T Test results showed that institutional ownership and audit audits had significant effect on earnings management, managerial ownership variables showed no significant effect on earnings management. The results of the F Test research is the composition of institutional ownership, managerial ownership and the audit board together have a significant influence on earnings management.
\end{abstract}

Keywords: Corporate Governance; earnings management; discretionary accruals.

\section{Pendahuluan}

Laporan keuangan entitas berperan menyiapkan informasi pada yang membutuhkan yaitu pemakai laporan intern maupun ekstern. Laporan keuangan menyatakan informasi tentang posisi keuangan entitas yang berkontribusi terhadap pemakainya. Beberapa informasi penting terdapat dalam laporan keuangan adalah laporan berisi laba entitas. Laporan laba dipergunakan pada pengukur kinerja entitas dan mempermudah pemegang saham atau pihak berkepentingan lainnya terhadap entitas untuk melakukan perkiraan laba entitas masa yang akan datang (Lestari \& Murtanto, 2018).

Tata kelola entitas bisa diartikan konsep dalam rangka menaikkan kinerja entitas melalui pengawasan prgoress kinerja anggota yang sekaligus menjamin pertanggung jawaban manajemen kepada stakeholder. (Hapsoro \& Hartomo, 2016).Teori Prospek menyatakan pengambilan keputusan terkait pendapatan atau biaya diartikan relatif pada reference point. Terkait tindakan manajer untuk menghindari kerugian, digunakan titik acuan atau disebut titik nol. Manajemen laba dilakukan supaya laba berada di atas titik nol 
(Vajriyanti, Subekti, \& Ghofar, 2016). Kepemlikan institusional berperan mengawasi manajemen dan kebijakan entitas. Tindakan pengawasan mengarahkan perhatian manajer terhadap perkembangan entitas, akhirnya dapat menurunkan perilaku manajemen laba (Lestari \& Murtanto, 2018).

Kepemilikan manajerial berperan mencegah kesempatan manajer dalam manajemen laba dengan melakukan lebih banyak upaya dalam memonitor tindakan manajer. Akibatnya, manajer akan bekerja sebaik mungkin untuk menghasilkan kualitas laba yang lebih tinggi (Puspita \& Kusumaningtyas, 2017). Studi empiris memberikan bukti campuran tentang dampak ukuran komite audit terhadap kualitas pelaporan keuangan. Tidak ditemukan hubungan yang signifikan antara jumlah direktur pada komite audit dan manajemen laba. Demikian pula, tidak ditemukan dampak ukuran komite audit terhadap penyajian kembali laba. Di sisi lain, (Dikria \& Mintarti, 2016) menemukan bahwa ukuran komite audit berhubungan negatif dengan manajemen laba, menyiratkan bahwa sejumlah minimum anggota komite audit mungkin relevan dengan kualitas pelaporan keuangan. GCG dalam komite audit menurut (Khafid \& Arief, 2017) adalah susunan, sistem dan proses organ-organ entitas dalam mengusahakan untuk memberikan nilai tambah terhadap entitas dalam jangka waktu yang cukup panjang (E Janrosl, 2019).

Dugaan kasus manipulasi laba terjadi pada entitas besar seperti manipulasi laporan keuangan yang dilakukan perusahaan multinasional teknologi dan jasa Amerika Serikat, General Electric (GE), dimana entitas menjanjikan imbal hasil besar pada investor. Namun sebenarnya, uang tidak benar-benar dihasilkan. Skema ini hanya ingin memutar uang investor baru untuk membayar hasil investor lama. Dalam sebuah laporan penelitian yang diterbitkan Harry Markopolos, investigator akuntansi dan keuangan AS, GE diduga memanipulasi keuangaannya hingga US\$ 38 miliar. Selama bertahun-tahun, perusahaan ini telah menghadapi masalah pelaporan akuntansi, mulai dari investigasi SEC hingga kesalahan pengelolaan investment banking senilai ratusan juta dollar AS.dihukum karena masalah terkait manipulasi laporan keuangan entitas (Wiegman, 2019). Berdasarkan kasus ini menimbulkan pertanyaan bagaimana mekanisme penerapan tata kelola entitas sebuah entitas untuk meminimalkan manajemen laba. Keberadaan tata kelola entitas diharapkan menekan kemungkinan terjadinya manajemen laba.Latar belakang dijelaskan diatas menyebakan ketertarikan peneliti mengenai Manajemen Laba.

\section{Landasan Teori}

Berbagai faktor yang membuat laporan angka akuntansi dapat dipengaruhi oleh berbagai pihak sehingga hasil laporan yang merupakan dasar keputusan para pemiliki saham bisa disesatkan, hal ini terjadi ketika pihak yang bertanggung jawab menilai dan menyusun laporan keuangan, menyesatkan pemakai laporan. Berikut beberapa faktor yang dapat mempengaruhi manajemen laba.

Model agensi adalah teori tertua dalam literatur manajemen dan ekonomi (Lestari \& Murtanto, 2018). Unsur-unsur tata kelola entitas memengaruhi manajemen entitas dalam menghasilkan laba yang diharapkan baik secara finansial maupun non-finansial. Sistem tata kelola (Good Corporate Governance - GCG) adalah sistem manajemen entitas yang 
menghubungkan para manajer, penyelia, pemegang saham dan pemangku kepentingan dengan menekankan lima prinsip GCG, yaitu transparan, pertanggungjawaban, tanggung Jawab, tidak memihak dan adil (Laksmi \& Kamila, 2018).

Kompensasi eksekutif adalah bagaimana upaya diperoleh dalam memotivasi manajer untuk berperilaku demi kepentingan pemegang saham berdasarkan ukuran kinerja seperti pendapatan akuntansi dan harga saham.Persiapan kompensasi eksekutif yaitu kepala sekolah dan manajer yang mengadakan kontrak agensi antara keduanya yang berupaya empersatukan kepentingan pemilik dan manajer. Ini dilakukan dengan merancang kompensasi manajerial berdasarkan kinerja keuangan yang ditentukan, yang mengasumsikan baik kinerja entitas jangka pendek dan jangka panjang mencakup pelaporan pendapatan dan kriteria tertentu terkait dengan rasio keuangan; serta harga saham di masa depan. Rencana insentif juga memungkinkan manajer untuk terlibat dalam perilaku entitas yang tidak konsisten dengan tujuan prinsip dengan tidak adanya mekanisme pengawasan dan kontrol yang kuat. Ini akan menunjukkan prevalensi, jika ada, motif EM terkait remunerasi di entitas UEA (Khan, Ghafar, \& Nair, 2019).

Komite audit disebut sebagai komite yang memiliki pertanggung jawaban pada dewan komisaris dalam membantu tugas dan fungsi dewan komisaris. Nilai perusahaan terkait dengan angka-angka pendapatan yang dilaporkan, itu menciptakan insentif ekonomi atau tekanan bagi manajemen untuk terlibat dalam manajemen laba. Jumlah anggota komite audit digunakan sebagai indikasi sumber daya yang tersedia untuk komite. Beberapa studi, seperti yang dari Jumlah anggota komite audit digunakan sebagai indikasi sumber daya yang tersedia untuk komite.Beberapa studi, menunjukkan bahwa jumlah anggota dalam komite audit mempengaruhi keputusannya (Lestari \& Murtanto, 2018).

Masalah yang berkaitan erat dengan kepemilikan manajerial adalah kepemilikan institusional. Namun demikian, ada perdebatan tentang pengaruh kepemilikan institusional terhadap kualitas laba.Di satu sisi, kecenderungan manajer untuk mengelola laba yang dilaporkan dapat dikurangi dengan efektivitas pemantauan eksternal oleh investor institusi.Beberapa investor institusi adalah "pemilik sementara" dan terlalu fokus pada laba saat ini.Kepemilikan institusional jangka pendek mendorong manajer untuk mengurangi investasi mereka dalam R\&D untuk menghasilkan pendapatan yang lebih tinggi.Hak pemegang saham yang kuat membuat manajer melaporkan kualitas laba yang lebih tinggi. Sebaliknya, ketika sebagian besar saham dimiliki oleh investor institusional jangka pendek, upaya pemegang saham untuk mengurangi agresivitas dan manajemen laba tidak akan efektif untuk menghasilkan pendapatan yang lebih tinggi (Khafid \& Arief, 2017).

Pernyataan manajer malas memprediksi bahwa persaingan pasar produk dan kepemilikan institusional adalah pengganti, jika persaingan tinggi maka tidak perlu pemantauan intensif karena manajer didisiplinkan oleh ancaman kebangkrutan untuk bekerja keras. Sebaliknya, model kepedulian karir kami memperkirakan bahwa persaingan yang lebih ketat memperkuat efek positif investasi institusional pada insentif manajerial (Bruno, 2019). 
Dibandingkan dengan perusahaan segmen tunggal, perusahaan dengan banyak segmen lebih cenderung memberi kompensasi kepada manajer mereka berdasarkan ukuran kinerja yang dapat diamati seperti pendapatan. Tingkat diversifikasi lini produk meningkat, penggunaan relatif tingkat divisi, ukuran kinerja berbasis akuntansi meningkat.Demikian pula, dalam mengevaluasi manajer divisi, penggunaan tingkat divisi, metrik berbasis akuntansi meningkat dengan diversifikasi. Selain itu, ia menemukan bahwa untuk perusahaan yang terdiversifikasi, metrik akuntansi divisi adalah yang paling penting, diikuti oleh metrik akuntansi perusahaan, dan harga saham perusahaan. Karena kompensasi manajemen dari perusahaan segmen tunggal lebih kecil kemungkinannya untuk dikaitkan dengan pendapatan divisi, pendapatan perusahaan segmen tunggal lebih kecil kemungkinannya untuk dimanipulasi. dalam peraturan DSAK-IAIPSAK 1 entitas dalam menyusun laporan keuangan harus atas dasar akrual, kecuali laporan arus kas (Sibarani, Thomas Junior, Hidayat, \& Surtikanti, 2015). Berdasarkan uraian diatas maka kerangka berpikir diilustrasikan sebagai berikut.

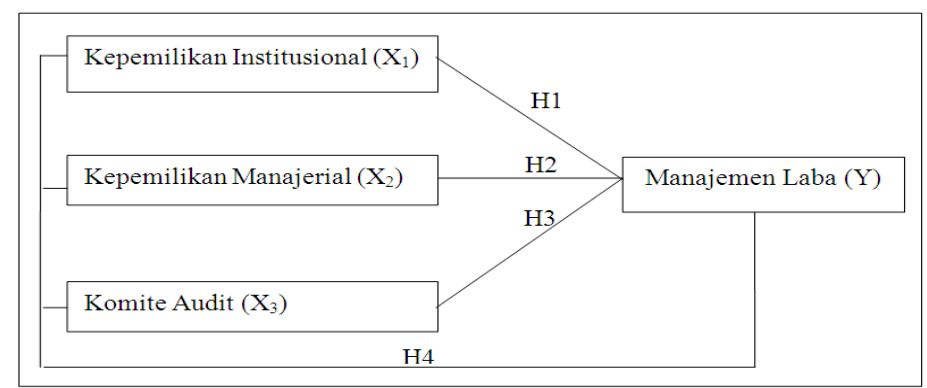

Gambar 1. Kerangka Berpikir

(Sumber: Penulis, 2019)

Berdasarkan ilustrasi diatas, hipotesis penelitian dikembangkan sebagai berikut:

H1: Kepemilikan institusional berpengaruh signifikan secara simultan terhadap manajemen laba.

H2: Kepemilikan manajerial berpengaruh signifikan secara simultan terhadap manajemen laba.

H3: Komite audit berpengaruh signifikan secara simultan terhadap manajemen laba.

H4: Kepemilikan Institusional, kepemilikan manajerial dan komite audit bersama-sama secara simultan berpengaruh signifikan terhadap manajemen laba

\section{Metodologi Penelitian}

Desain penelitian diperlukan sebagai kerangka dalam menyusun penelitian. Rancangan penelitian bertujuan untuk membantu peneliti menjawab pertanyaan secara akurat, valid dan obyektif. Dalam penelitian ini digunakan penelitian kuantitatif yang bertujuan untuk mendapatkan hasil pengaruh variabel terikat (independent) yaitu kepemilikan institusional, kepemilikan manajerial dan komite audit pada variabel terikat (dependent) yaitu manajemen laba. Lokasi penelitian dalam penelitian ini dilakukan di Bursa Efek Indonesia Kantor Perwakilan Kepulauan Riau yang berlokasi di kompleks Mahkota Raya Blok A No. 11, Batam melalui www.idx.co.id. Populasi penelitian ini adalah laporan keuangan entitas 
perdagangan, jasa dan investasi subsektor perdagangan eceran rentang tahun 2014-2018, berjumlah 27 entitas dan diperoleh sampel sebanyak 10 entitas dengan menggunakan metode proposive sampling. Variabel operasional mencakup kesamaan karakter atau nilai dari suatu objek yang memiliki variasi atau keberagaman yang sama untuk penelitian sehingga dapat ditarik kesimpulan. Data yang dikumpulkan dianalisis dengan metode anlisis statistik deskriptif dan uji hipotesis, kemudian diolah software SPSS versi 25. Metode analisis berupa analisis regresi linear berganda.

\section{Hasil Dan Pembahasan}

\subsection{Statistik Deskriptif}

Analisis ini bertujuan menggambarkan serta mendeskripsikan hasil penelitian agar memudahkan pemahaman terhadap data. Hasil analisis deskriptif diilustrasikan.

Tabel 1. Descriptive Statistics

\begin{tabular}{lr|r|r|r|r}
\hline & $\mathrm{N}$ & \multicolumn{1}{c|}{ Minimum } & \multicolumn{1}{c|}{ Maximum } & \multicolumn{1}{c}{ Mean } & \multicolumn{1}{c}{ Std. Deviation } \\
\hline Kepemilikan Institusional & 50 & .52325 & .86719 & .6780294 & .11316607 \\
\hline Kepemilikan Manajerial & 50 & .00000 & .11529 & .0239957 & .03555823 \\
\hline Komite Audit & 50 & 3 & 4 & 3.12 & .328 \\
\hline Manajemen Laba & 50 & -.05441 & .18785 & .0850808 & .04714359 \\
\hline Valid N (listwise) & 50 & & & & \\
\hline
\end{tabular}

(Sumber: SPSS 25,2019)

Dapat disimpulkan bahwa sampel data penelitian sebanyak 50. Variabel kepemilikan institusional bernilai minimun 0,52325, maximun 0,86719, mean 0,67802 dan standar deviasi 0,11316. Variabel kepemilikan manajerial bernilai minimun 0,00000, maximun 0,11529, mean 0,02399 dan standar deviasi 0,03555. Variabel komite audit bernilai minimun 3, maximun 4, mean 3,12 dan standar deviasi 0,328.

\subsection{Uji Asumsi Klasik}

\section{Uji Normalitas}

Pengujian normalitas diperlukan untuk mengamati gambaran normalitas data. Tahap normalitas data diamati menggunakan histogram, p-lot dan uji Kolmogorov-Smirnov. 


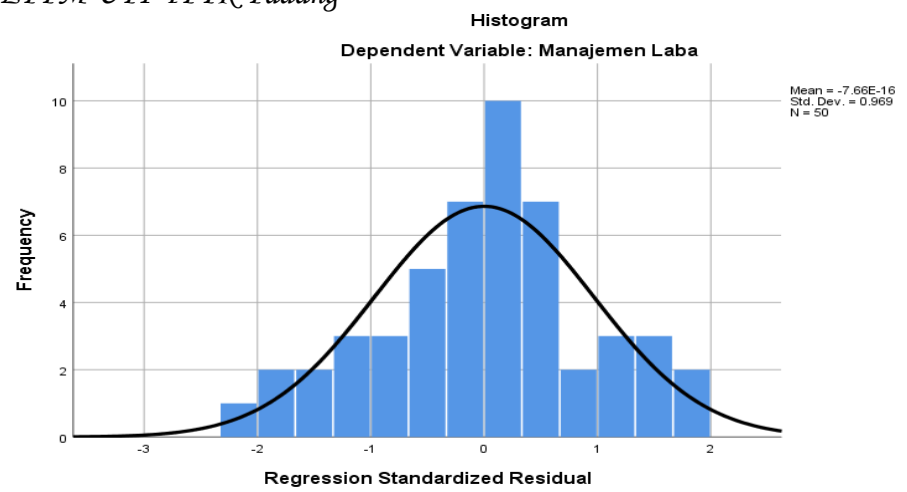

Gambar 2. Grafik Histogram

(Sumber: SPSS 25, 2019)

Grafik histogram diatas telah menyerupai lonceng sehingga syarat normalitas data telah terpenuhi.

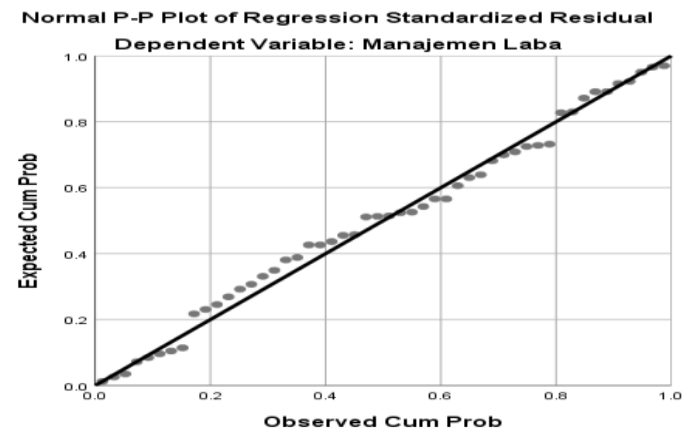

Gambar 3.Uji Normal P-Plot

(Sumber: SPSS 25, 2019)

Pada gambar p-plot, diamati data telah menigkuti garis diagonal sehingga syarat normalitas telah terpenuhi.

Tabel 2. Uji Normalitas

One-Sample Kolmogorov-Smirnov Test

\begin{tabular}{llr}
\hline & & Unstandardized Residual \\
\hline $\mathrm{N}$ & & 50 \\
\hline Normal Parameters $^{\mathrm{a}, \mathrm{b}}$ & Mean & .0000000 \\
\cline { 2 - 3 } & Std. Deviation & .03819290 \\
\hline \multirow{2}{*}{ Most Extreme Differences } & Absolute & .064 \\
\cline { 2 - 3 } & Positive & .062 \\
\cline { 2 - 3 } & Negative &. .064 \\
\hline Test Statistic & & .064 \\
\hline Asymp. Sig. (2-tailed) & & $.200^{c, d}$ \\
\hline
\end{tabular}

(Sumber: SPSS 25, 2019) 
Pengujian Kolmogorov-Smirnov membuktikan data telah berdistribusi normal dengan tingkat signifikansi 0,200 (>)0,05.

\section{Uji Autokorelasi}

Tahap pengujian ini bertujuan mengamati keterkaitan antar variabel periode $\mathrm{t}$ dengan periode lalu.

\begin{tabular}{|c|c|c|c|c|c|}
\hline \multicolumn{6}{|c|}{$\begin{array}{c}\text { Tabel 3. Uji Autokorelasi } \\
\text { Model Summaryb }\end{array}$} \\
\hline Model & $\mathrm{R}$ & R Square & Adjusted R Square & $\begin{array}{l}\text { Std. Error of the } \\
\text { Estimate }\end{array}$ & Durbin-Watson \\
\hline 1 & $.586^{\mathrm{a}}$ & .344 & .301 & .03941866 & 1.696 \\
\hline
\end{tabular}

(Sumber: SPSS 25,2019)

Dapat diamati pada tingkat signifikan 5\% jumlah sampel 50 (n), jumlah independen 3 $(\mathrm{k}=3)$. Nilai pada kolom durbinwatson dengan nilai 1,696 dan berada antara 1,673 (du) $<1,696<2,326$ (4-du) maka bebas gejala autokorelasi.

\section{Uji Heteroskedastisitas}

Pada tahapan ini, data diuji untuk di amati keberagaman variance antar variabel. Hasil uji diilustrasikan sebagai berikut.

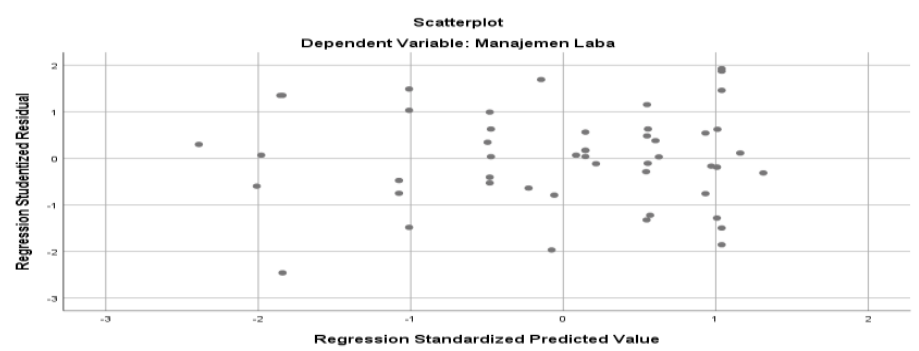

Gambar 4. Uji Scatterplot

(Sumber: SPSS 25, 2019)

Grafik plot menampilkan titik-titik tidak beraturan atau tidak membentuk suatu pola tertentu serta titik berada dibawah dan diatas 0 . Hal ini mengindikasikan bahwa tidak terjadi heteroskedastisitas

\section{Uji Multikolinearitas}

Dalam model analisis linear berganda, asumsi multikolinearitas mencegah adanya hubungan dalam variabel independen. 


\begin{tabular}{|c|c|c|c|c|c|c|c|c|}
\hline \multirow{2}{*}{\multicolumn{2}{|c|}{ Model }} & \multicolumn{2}{|c|}{$\begin{array}{l}\text { Unstandardized } \\
\text { Coefficients }\end{array}$} & \multirow{2}{*}{$\begin{array}{c}\text { Standardized } \\
\text { Coefficients } \\
\text { Beta }\end{array}$} & \multirow[b]{2}{*}{$\mathrm{t}$} & \multirow[b]{2}{*}{ Sig. } & \multicolumn{2}{|c|}{$\begin{array}{l}\text { Collinearity } \\
\text { Statistics }\end{array}$} \\
\hline & & $\mathrm{B}$ & $\begin{array}{l}\text { Std. } \\
\text { Error }\end{array}$ & & & & Tolerance & VIF \\
\hline \multirow[t]{4}{*}{1} & (Constant) & .477 & .084 & & 5.665 & .000 & & \\
\hline & Kepemilikan Institusional & -.151 & .056 & -.363 & -2.693 & .010 & .787 & 1.271 \\
\hline & Kepemilikan Manajerial & -.249 & .163 & -.188 & -1.531 & .133 & .947 & 1.056 \\
\hline & Komite Audit & -.091 & .019 & -.632 & -4.704 & .000 & .790 & 1.266 \\
\hline
\end{tabular}

(Sumber: SPSS 25,2019)

Dapat diamati nilai tolerance dan VIF variabel di atas. Kepemilikan institusional bernilai 0,787 dan 1,271. Kepemilikan manajerial bernilai 0,947 dan 1,056. Komite audit bernilai 0,790 dan 1,266. Disimpulkan, tidak terjadimultikolinearitas terhadap setiap variabel.

\subsection{Uji Hipotesis}

\section{Hasil Uji T}

Digunakan untuk mengetahui pengaruh variabel independen atau bebas (X) terhadap variabel dependen atau terikat (Y).

Tabel 5. Uji Statistik T Coefficients ${ }^{a}$

\begin{tabular}{|c|c|c|c|c|c|c|}
\hline \multirow{2}{*}{\multicolumn{2}{|c|}{ Model }} & \multicolumn{2}{|c|}{$\begin{array}{l}\text { Unstandardized } \\
\text { Coefficients }\end{array}$} & \multirow{2}{*}{$\begin{array}{l}\text { Standardized } \\
\text { Coefficients } \\
\text { Beta }\end{array}$} & \multirow[b]{2}{*}{$\mathrm{T}$} & \multirow[b]{2}{*}{ Sig. } \\
\hline & & $\mathrm{B}$ & Std. Error & & & \\
\hline \multirow[t]{4}{*}{1} & (Constant) & .477 & .084 & & 5.655 & .00000 \\
\hline & Kepemilikan Institusional & -.151 & .056 & -.363 & -2.693 & .00984 \\
\hline & Kepemilikan Manajerial & -.249 & .163 & -.188 & -1.531 & .13272 \\
\hline & Komite Audit & -.091 & .019 & -.632 & -4.704 & .00002 \\
\hline
\end{tabular}

(Sumber: SPSS 25,2019)

Pada pengujian $\mathrm{t}$, maka hasil yang diamati menunjukkan:

1. Variabel kepemilikan institusional dengan tingkat signifikan $0,00984<0,05$ dan $t$ hitung sebesar -2,693 dan t table 2,013 disimpulkan kepemilikan institusional berpengaruh signifikan terhadap manajemen laba.

2. Variabel kepemilikan manajerial dengan tingkat signifikan $0,13272>0,05$ dan $t$ hitung sebesar -1,531 dan t table 2,013 disimpulkan kepemilikan manajerial tidak berpengaruh signifikan terhadap manajemen laba

3. Variabel komite audit dengan tingkat signifikan $0,00002<0,05$ dan t hitung sebesar $-4,704$ dan $\mathrm{t}$ table 2,013 disimpulkan komite audit berpengaruh signifikan terhadap manajemen laba 


\section{Hasil Uji F}

Uji statistik F digunakan untuk menguji pengaruh variabel bebas secara bersama - sama terhadap variabel tergantung (Sugiyono, 2018).

Tabel 6. Uji Statistik F ANOVA ${ }^{a}$

\begin{tabular}{llr|r|r|r|r}
\hline Model & & Sum of Squares & df & Mean Square & F & Sig. \\
\hline \multirow{2}{*}{1} & Regression & .037 & 3 & .012 & 8.029 & $.0002^{\mathrm{b}}$ \\
\cline { 2 - 7 } & Residual & .071 & 46 & .002 & & \\
\cline { 2 - 7 } & Total & .109 & 49 & & \\
\hline \multicolumn{7}{c}{ (Sumber: SPSS 25,2019) }
\end{tabular}

Hasil uji menunjukkan bahwa tingkat taraf signifkansi sebesar 0,0002 $<0,05$ maka dapat disimpulkan bahwa ketiga variabel independen bersama-sama secara simultan berpengaruh signifikan terhadap manajemen laba.

\section{Uji Koefisien Determinasi}

Uji koefisiendeterminasi diperlukan untuk mengetahui tingkatpengaruh yang dihasilkan oleh model regresi terhadap variabel yang menjadi titik fokus penelitian.

Tabel 7. Koefisien Determinasi Model Summary ${ }^{b}$

\begin{tabular}{rr|r|r|r|r}
\hline & & & & \\
Model & $\mathrm{R}$ & R Square & Adjusted R Square & $\begin{array}{c}\text { Std. Error of the } \\
\text { Estimate }\end{array}$ & \multicolumn{1}{c}{ Durbin-Watson } \\
\hline 1 & $.586^{\mathrm{a}}$ & .344 & .301 & .03941866 & 1.696 \\
\hline
\end{tabular}

(Sumber: SPSS 25,2019)

Hasil penelitian menunjukkan R2 sebesar 0,344 atau 34,4\%, sehingga dapat disimpulkan manajemen laba dipengaruhi kepemilikan institusional, kepemilikan manajerial dan komite audit sebesar $34,4 \%$ dan sisanya $65,6 \%$ dipengaruhi oleh faktorfaktor lainnya yang tidak dimasukkan dalam penelitian ini seperti ukuran entitas, profitabilitas, solvabilitas dan lainnya.

\section{Pengaruh Kepemilikan Institusional terhadap Manajemen Laba}

Pengujian tentang apakah kepemilikan institusional memiliki pengaruh signifikan terhadap manajemen laba dinyatakan dengan hasil uji statistik $\mathrm{T}$ yang memperlihatkan thitung sebesar -2,693 dan ttabel sebesar 2,013 serta taraf signifikansi sebesar 0,00984 < 0,05 , terlihat bahwa taraf signifikansi lebih kecil dari $5 \%$ yang berarti variabel independen memiliki pengaruh terhadap variabel independen maka dapat disimpulkan kepemilikan institusional memiliki pengaruh signifikan terhadap manajemen laba. Hasil pengujian ini didukung oleh hasil penelitian dari Cornett et al., (2012) dalam (Lestari \& Murtanto, 2018) yang mengemukakan bahwa kepemilikan institusional mempengaruhi manajemen laba karena kepemilikan institusional yang tinggi dinilai mampu mengurangi motivasi manajer dalam intervensi laporan keuangan sehingga tidak merugikan investor.

\section{Pengaruh Kepemilikan Manajerial terhadap Manajemen Laba}


Pengujian tentang apakah kepemilikan manajerial memiliki pengaruh signifikan terhadap manajemen laba dinyatakan dengan hasil uji statistik $\mathrm{T}$ yang memperlihatkan thitung sebesar -1,531 dan tabel sebesar 2,013 serta taraf signifikansi sebesar 0,13272 > 0,05, maka dapat disimpulkan dengan taraf signifikansi lebih besar dari 5\% bahwa kepemilikan manajerial tidak memiliki pengaruh signifikan terhadap manajemen laba. Kesimpulan ini dikemukakan karena kepemilikan manajerial entitas di Indonesia sangat kecil dengan rata-rata di bawah 5\% sehingga para manajer yang juga memiliki saham entitas tersebut cenderung mengkuti cara mengelola laba dari sudut pandang keinginan investor.

\section{Pengaruh Komite Audit terhadap Manajemen Laba}

Pengujian tentang apakah komite audit memiliki pengaruh signifikan terhadap manajemen laba dinyatakan dengan hasil uji statistik $\mathrm{T}$ yang memperlihatkan thitung sebesar -4,704 dan ttabel sebesar 2,013 serta taraf signifikansi sebesar 0,00002 $<0,05$, maka dapat disimpulkan berdasarkan taraf signifikansi lebih kecil dari 5\% bahwa komite audit memiliki pengaruh signifikan terhadap manajemen laba. Hasil pengujian ini didukung oleh hasil penelitian (Irma, 2019) yang menyatakan semakin banyak jumlah komite audit maka akan semakin banyak pula pengendalian dan pengawasan yang dilakukan, pengendalian internal entitas sangat dipengaruhi atas pertimbangan keputusan dari komite audit yang berasal dari pendidikan yang berbeda-beda, sehingga mencegah kesempatan dan motivasi bagi segala pihak untuk melakukan manajemen laba.

\section{Pengaruh Kepemilikan Institusional, Kepemilikan Manajerial dan Komite Audit terhadap Manajemen Laba}

Pengujian tentang apakah kepemilikan institusional, kepemilikan manajerial dan komite audit bersama-sama secara simultan memiliki pengaruh signifikan terhadap manajemen laba dinyatakan dengan hasil uji statistik $\mathrm{F}$ yang memperlihatkan tingkat taraf signifkansi sebesar 0,0002 <0,05, maka dapat disimpulkan berdasarkan taraf signifikansi lebih kecil dari 5\% bahwa kepemilikan institusional, kepemilikan manajerial dan komite audit bersama-sama secara simultan berpengaruh signifikan terhadap manajemen laba.

\section{Kesimpulan}

Berdasarkan hasil analisis data, pengujianhipotesis yang telah disusun dan dijelaskan sebelumnya maka disimpulkan sebagaiberikut:

1. Kepemilikan institusional memiliki pengaruh signifikan terhadap manajemen laba, maka dapat disimpulkan bahwa kepemilikan institusional mampu mengurangi terjadinya manajemen laba.

2. Kepemilikan manajerial tidak memiliki pengaruh signifikan terhadap manajemen laba, maka kepemilikan manajerial disimpulkan tidak dapat menjadi tolak ukur menekan manajemen laba, hal ini juga disebabkan karna rata-rata manajemen tidak memiliki kepemilikan saham dalam entitas.

3. Komite audit memiliki pengaruh signifikan terhadap manajemen laba, karena komite audit memiliki peran penting dalam pengendalian internal entitas, keputusan yang 
Jurnal EKOBISTEK, Vol.9, $\mathcal{N}$ o. 1, April 2020, Hal 49-52 | ISSN: 2301-5268 | E-ISSN : 2527-9483 |

Copyright@2020 6y LPPM VPI YPTK Padang

dinyatakan komite audit didasari atas temuan-temuan yang dianggap perlu diperbaiki demi mencegah berbagai risiko yang mungkin terjadi.

4. Kepemilikan Institusional, kepemilikan manajerial dan komite audit bersama-sama secara simultan berpengaruh signifikan terhadap manajemen laba

\section{DAFTAR PUSTAKA}

Bruno, L. (2019). Innovation And Institutional Ownership. Journal Of Chemical Information And Modeling, 53(9), 1689-1699.

Https://Doi.Org/10.1017/Cbo9781107415324.004

Dikria, O. Dan, \& Mintarti, S. U. (2016). Pengaruh Literasi Keuangan Dan Pengendalian Diri Terhadap Perilaku Konsumtif Mahasiswa Jurusan Ekonomi Pembangunan 
Fakultas Ekonomi Universitas Negeri Malang Angkatan 2013. Jurnal Pendidikan Ekonomi, 9(2), 128-139.

Hapsoro, D., \& Hartomo, A. B. (2016). Keberadaan Corporate Governance Sebagai Variabel Moderasi Pengaruh Financial Distress Terhadap Earnings Management. Jurnal Ekonomi Dan Bisnis, 19(1), 91. Https://Doi.Org/10.24914/Jeb.V19i1.507

Irma, A. D. A. (2019). Pengaruh Komisaris, Komite Audit, Struktur Kepemilikan, Size, Dan Leverage Terhadap Kinerja Keuangan Perusahaan Properti, Perumahan Dan Konstruksi 2013-2017. Jurnal Ilmu Manajemen, 7(3), 697-712.

Khafid, M., \& Arief, S. (2017). Managerial Ownership, Corporate Governance And Earnings Quality: The Role Of Institutional Ownership As Moderating Variable.

Pertanika Journal Of Social Sciences And Humanities, 25(October 2017), 241-254.

Khan, Y., Ghafar, A., \& Nair, M. (2019). Earnings Management In The Presence Of Corporate Governance Quality: Evidence From The Uae (2007-2011).

Laksmi, A. C., \& Kamila, Z. (2018). The Effect Of Good Corporate Governance And Earnings Management To Corporate Social Responsibility Disclosure. Academy Of Accounting And Financial Studies Journal, 22(1). Retrieved From Https://Www.Abacademies.Org/Articles/The-Effect-Of-Good-CorporateGovernance-And-Earnings-Management-To-Corporate-Social-ResponsibilityDisclosure-6879.Html

Lestari, E., \& Murtanto, M. (2018). Pengaruh Efektivitas Dewan Komisaris Dan Komite Audit, Struktur Kepemilikan, Dan Kualitas Audit Terhadap Manajemen Laba. Media Riset Akuntansi, Auditing \& Informasi, 17(2), 97.

Https://Doi.Org/10.25105/Mraai.V17i2.2063

Puspita, E., \& Kusumaningtyas, D. (2017). Pengaruh Mekanisme Kepemilikan Manajerial, Kecakapan Manajerial, Tingkat Pengungkapan Laporan Keuangan Terhadap Manajemen Laba Dengan Kualitas Audit Sebagai Variabel Intervening. 31-35. Retrieved From Http://Ojs.Unpkediri.Ac.Id

Sibarani, Thomas Junior, Hidayat, N., \& Surtikanti. (2015). Analisis Pengaruh Beban Pajak Tangguhan, Discretionary Accruals , Dan Arus Kas Operasi Terhadap Manajemen Laba. Jurnal Riset Akuntansi Dan Perpajakan, 2(1), 19-31. Https://Doi.Org/10.1029/2004tc001767

Sugiyono. (2018). Metode Penelitian Kuantitatif,Kualitatif Dan R\$D (27th Ed.; Alfabeta, Ed.). Bandung: Alfabeta.

Vajriyanti, E., Subekti, I., \& Ghofar, A. (2016). Pengaruh Mekanisme Komite Audit Terhadap Manajemen Laba : Laba Untuk Menghindari Kerugian. Jurnal Reviu Akuntansi Dan Keuangan, 6(1), 801-810. Retrieved From Http://Ejournal.Umm.Ac.Id/Index.Php/Jrak/Article/Download/5076/5044 